\title{
Infestation of shore crab gills by a free-living mussel species
}

\author{
Rowan Poulter $^{1} \cdot$ P. Graham Oliver $^{2} \cdot$ Chris Hauton $^{1} \cdot$ Trystan Sanders $^{3}$. \\ Benjamin J. Ciotti ${ }^{1,4}$
}

Received: 24 March 2016 /Revised: 13 December 2016 / Accepted: 28 December 2016 / Published online: 24 January 2017

(C) The Author(s) 2017. This article is published with open access at Springerlink.com

\begin{abstract}
Parasitic and commensal species can impact the structure and function of ecological communities and are typically highly specialized to overcome host defences. Here, we report multiple instances of a normally free-living species, the blue mussel Mytilus edulis Linnaeus, 1758, inhabiting the branchial chamber of the shore crab Carcinus maenas (Linnaeus, 1758) collected from widely separated geographical locations. A total of 127 C. maenas were examined from four locations in the English Channel, one location in the Irish Sea and two locations at the entrance of the Baltic Sea. The branchial chambers of three crabs (one from the English Channel and two from Gullmar Fjord, Sweden) were infested with mussels resembling the genus Mytilus. Sequencing at the Me15/16 locus on the polyphenolic adhesive protein gene confirmed the identity as M. edulis. Bivalve infestation always occurred in larger red male individuals. Up to 16 mussels, ranging from 2 to $11 \mathrm{~mm}$ in shell length, were found in each individual, either wedged between gill lamellae or attached to the branchial chamber inner wall. This is one of the first reports of a bivalve inhabiting crustacean gills and is an
\end{abstract}

Communicated by V. Urgorri

Benjamin J. Ciotti

benjamin.j.ciotti@gmail.com

1 Ocean and Earth Science, National Oceanography Centre Southampton, University of Southampton, European Way, Southampton SO14 3ZH, UK

2 National Museum of Wales, Cardiff CF10 3NP, Wales

3 Marine Ecology, GEOMAR Helmholz Centre for Ocean Research, Kiel, Germany

4 School of Biological and Marine Sciences, Plymouth University, Plymouth PL4 8AA, UK intriguing case of a normally free-living prey species infesting its predator.

Keywords Commensal · Infestation · Mussel-bound · Parasite $\cdot$ Predator-prey interaction $\cdot$ Shore crab

\section{Introduction}

While parasitism and commensalism typically require a high level of specialisation, free-living non-specialists are occasionally found to colonise other species (Rohde 1984). For the coloniser this can offer both benefits, by increasing dispersal, providing access to food, removing waste products and offering protection (Key et al. 1996; Wahl 1989; Walker 1974), and disadvantages, by exposing them to stressful environmental conditions (Bruce 1989) and antifouling mechanisms of the host. Successful colonisation can also have negative implications for the host, such as reduced reproductive success and survival rates (Minchella 1985). Through impacts on host or coloniser populations, these instances of colonisation have the potential to influence the structure and function of ecological communities (Hatcher et al. 2006; Mouritsen and Poulin 2005; Poulin 1999; Poulin and Mouritsen 2006).

Certain taxa have managed to overcome anti-fouling grooming structures and behaviours in order to colonise the exoskeleton and branchial chambers of crustaceans (Bauer 1989). Commensal barnacles Octolasmis spp. infest branchial chambers and gills of numerous crustacean species (Gannon and Wheatly 1992; Santos and Bueno 2002; Walker 1974). Bopyrid parasites (e.g. Pseudione spp.) inhabit branchial chambers of decapod crustaceans (Boyko et al. 2012; McDermott 1991; Mori et al. 1999). Crustacean branchial chambers also host a variety of protozoa, helminths and crustaceans, most of which are small and highly specialised for 
survival and reproduction within the host (Shields 1992). However, aside from one observation of blue mussel Mytilus edulis Linnaeus, 1758, post-larvae on Paralithodes camtschaticus (Tilesius, 1815) gills (Jansen et al. 1998), we are not aware of any examples of bivalves inhabiting the internal structures or branchial chambers of crustaceans.

Bivalves, principally those belonging to the superfamily Galeommatoidea, certainly have the potential to associate with a range of invertebrates, including echinoids, holothurians, polychaetes, sipunculans, echiurids, brachiopods and crustaceans ( $\mathrm{Li}$ et al. 2012). In some cases, bivalves inhabit internal structures of other organisms, such as the respiratory chamber of polychaetes (Rosewater 1984) or the oesophagus of holothurians (Bristow et al. 2010), or are embedded in the tissues of sessile organisms such as ascidians (Bodger and Allen 2008). Associations with crustaceans are mostly restricted to the burrows or undersides of burrowing forms such as Upogebia sp., Squilla sp. and Lysiosquilla sp. (Li et al. 2012). Isaeva et al. (2001) found that the free-living bivalves Mytilus trossulus Gould, 1850, and Hiatella arctica (Linnaeus, 1767) could be facultative epibionts on Hemigrapsus sanguineus (De Haan, 1835) when normal cleaning behaviour was interrupted by rhizocephalan parasites. Overall, however, association with decapod crabs is rare and, again, limited to external attachment (Boss 1965; Goto et al. 2007; Kato and Itani 1995; Kosuge and Itani 1994; Lützen and Takahashi 2003; Morton 1972). While bivalves are able to form commensal relationships with a wide range of hosts, this association is largely restricted to the Galeommatoidea, and there are few records of such interactions between Mytiloidea and other free-living invertebrates.

We provide one of the first documented examples of a bivalve inhabiting the branchial chamber of a brachyuran crustacean. We report multiple instances of the normally free-living M. edulis in the branchial chamber of the shore crab Carcinus maenas (Linnaeus, 1758) collected from widely separated geographical locations.

\section{Materials and methods}

C. maenas were collected from seven sites between November 2014 and March 2015 (Table 1). Between 15 and 22 crabs were sampled from each location using baited lines or traps. Individuals from Menai Straits, Mudeford Quay, Swanwick Jetty, Weymouth Harbour and Newton's Cove were stored in full-salinity aquarium tanks for a maximum of 2 weeks prior to examination. Individuals from Kiel Fjord and Gullmar Fjord were stored in ambient water from collection locations for a maximum of 5 weeks prior to examination.

The mass, carapace width $(\mathrm{CW})$, sex and any external signs of damage or disease were recorded for each crab. The colour of the legs, claws and carapace underside was also noted. The carapace was then carefully removed and gills were examined with the naked eye. The number and location of bivalves inhabiting the gill chamber were recorded. Samples of bivalves encountered were fixed in Bouin's solution and stored in alcohol (Gullmar Fjord) or frozen at $-80{ }^{\circ} \mathrm{C}$ (Newton's Cove) for genotyping.

A small piece $\left(c a .0 .1 \mathrm{~mm}^{3}\right)$ of gill tissue from each attached mussel was extracted for genotyping using the Me15/16 locus on the polyphenolic adhesive protein gene, which is diagnostic for species of the genus Mytilus (Inoue et al. 1995). DNA was extracted using the DNeasy ${ }^{\circledR}$ Blood \& Tissue Kit (Qiagen, Manchester, UK) according to the manufacturer's protocol. Formalin-fixed/alcohol-preserved tissue was washed twice in phosphate-buffered saline prior to DNA extraction. The target sequence was amplified by polymerase chain reaction (PCR) using sense primer Me15 5'- CCAGTATACAAACC TGTGAAGA $-3^{\prime}$ and antisense primer Me16 5'TGTTGTCTTAATAGGTTTGTAAGA-3' (Inoue et al. 1995). PCR was performed with the GoTaq ${ }^{\circledR}$ G2 Flexi DNA Polymerase kit (Promega, Southampton, UK). Reactions were set up in a $50-\mu$ l volume containing $1 \mathrm{X} \mathrm{GoTaq}{ }^{\circledR}$ Flexi Buffer, $2.5 \mathrm{mM} \mathrm{MgCl}_{2}, 0.2 \mathrm{mM}$ deoxyribonucleotide phosphates mix, $0.5 \mu \mathrm{M}$ of sense and antisense primers and $1.25 \mathrm{U}_{\text {of GoTaq }}{ }^{\circledR}$ G2 Flexi DNA polymerase. The reaction mix was pre-heated at $95{ }^{\circ} \mathrm{C}$ for $2 \mathrm{~min}$, then subjected to 35 temperature cycles followed by a final extension step of $5 \mathrm{~min}$ at $72^{\circ} \mathrm{C}$. Each cycle consisted of $30 \mathrm{~s}$ at $95{ }^{\circ} \mathrm{C}, 30 \mathrm{~s}$ at $56{ }^{\circ} \mathrm{C}$ and $30 \mathrm{~s}$ at $72{ }^{\circ} \mathrm{C}$. Twenty microlitres of each PCR product was subjected to electrophoresis (72 V for $40 \mathrm{~min}$ ) against a 100 -bp DNA ladder (New England BioLabs, Hitchin, UK) on 2\% agarose/TAE gel containing $0.5 \mu \mathrm{g} \mathrm{ml}^{-1}$ ethidium bromide. Gels were visualised under UV radiation to reveal clear amplicons of ca. $180 \mathrm{bp}$. Amplicons were excised with a scalpel, extracted with a QIAquick ${ }^{\circledR}$ Gel Extraction Kit (Qiagen) and eluted with $30 \mu \mathrm{l}$ sterile water. Two microlitres of the extract was cloned using the pGEM $^{\circledR}$-T Easy Vector System (Promega) following the manufacturer's protocol. Four successful transformants for each sample were grown overnight at $37{ }^{\circ} \mathrm{C}$ in Luria broth containing $100 \mu \mathrm{g} \mathrm{ml}^{-1}$ ampicillin. Cultures were centrifuged at $1000 x G$ for $10 \mathrm{~min}$, and DNA was extracted from the pellet using a QIAprep ${ }^{\circledR}$ Spin Miniprep Kit (Qiagen). Purified plasmids were subject to conventional Sanger sequencing using standard M13 primers (Source BioScience, Oxford, UK).

\section{Results}

Bivalves were found in the branchial chambers of $C$. maenas from widely separated populations (Table 1). At Gullmar Fjord, Sweden, bivalves were found in two (out of 20 sampled) $C$. maenas individuals. One of the infested $C$. maenas contained six bivalves, while the second contained 16 bivalves and had died during holding. Bivalves were located 
Table 1 Summary of Carcinus maenas populations sampled and bivalve infestations observed

\begin{tabular}{|c|c|c|c|c|c|c|c|c|c|c|}
\hline Site & Location & Date & $\begin{array}{l}\text { Collection } \\
\text { depth (m) }\end{array}$ & $\begin{array}{l}\text { Collection } \\
\text { method }\end{array}$ & $\begin{array}{l}\text { No. } \\
\text { crabs } \\
\text { examined }\end{array}$ & $\begin{array}{l}\text { Mean } \\
\mathrm{CW}^{\mathrm{a}} \pm 1 \\
\mathrm{SD}(\mathrm{mm})\end{array}$ & $\begin{array}{l}\% \\
\text { Male }\end{array}$ & $\begin{array}{l}\% \\
\operatorname{Red}^{\mathrm{b}}\end{array}$ & $\begin{array}{l}\text { No. } \\
\text { crabs } \\
\text { infested }\end{array}$ & $\begin{array}{l}\text { No. } \\
\text { bivalves }\end{array}$ \\
\hline Swanwick Jetty, UK & $\begin{array}{l}50^{\circ} 53^{\prime} 16^{\prime \prime} \mathrm{N} \\
1^{\circ} 17^{\prime} 46^{\prime \prime} \mathrm{W}\end{array}$ & Nov-14 & $0-1.0$ & Line & 20 & $37.4 \pm 7.8$ & 55 & 5 & 0 & 0 \\
\hline Mudeford Quay, UK & $\begin{array}{l}50^{\circ} 43^{\prime} 30^{\prime \prime} \mathrm{N} \\
1^{\circ} 44^{\prime} 23^{\prime \prime} \mathrm{W}\end{array}$ & Nov-14 & $0-1.5$ & Line & 20 & $41.5 \pm 9.3$ & 40 & 40 & 0 & 0 \\
\hline Weymouth Harbour, UK & $\begin{array}{l}50^{\circ} 36^{\prime} 28^{\prime \prime} \mathrm{N} \\
2^{\circ} 26^{\prime} 59^{\prime \prime} \mathrm{W}\end{array}$ & Nov-14 & $0-0.5$ & Line & 15 & $37.8 \pm 5.4$ & 27 & 20 & 0 & 0 \\
\hline Newton's Cove, UK & $\begin{array}{l}50^{\circ} 36^{\prime} 15^{\prime \prime} \mathrm{N} \\
2^{\circ} 27^{\prime} 01^{\prime \prime} \mathrm{W}\end{array}$ & Nov-14 & $0-1.0$ & Line & 15 & $49.0 \pm 6.0$ & 100 & 80 & 1 & 1 \\
\hline Gullmar Fjord, Sweden & $\begin{array}{l}58^{\circ} 15^{\prime} 28^{\prime \prime} \mathrm{N} \\
11^{\circ} 27^{\prime} 28^{\prime \prime} \mathrm{E}\end{array}$ & Nov-14 & $0-15$ & Trap & 20 & $69.0 \pm 3.9$ & 100 & 68 & 2 & 22 \\
\hline Menai Straits, UK & $\begin{array}{l}53^{\circ} 13^{\prime} 39^{\prime \prime} \mathrm{N} \\
4^{\circ} 09^{\prime} 18^{\prime \prime} \mathrm{W}\end{array}$ & Dec-14 & $<4.0$ & Trap & 15 & $57.6 \pm 4.8$ & 100 & 40 & 0 & 0 \\
\hline Kiel Fjord, Germany & $\begin{array}{l}54^{\circ} 25^{\prime} 22^{\prime \prime} \mathrm{N} \\
10^{\circ} 12^{\prime} 09^{\prime \prime} \mathrm{E}\end{array}$ & Mar-15 & $0-2.0$ & Trap & 22 & $57.7 \pm 5.4$ & $\mathrm{~N} / \mathrm{A}$ & N/A & 0 & 0 \\
\hline
\end{tabular}

${ }^{\mathrm{a}} \mathrm{CW}=$ Carapace width

${ }^{\mathrm{b}} \mathrm{Crab}$ colouration classified as red or green

in both right and left branchial chambers around the fifth gill, either wedged between gill lamellae or attached to the surrounding branchial chamber wall (Fig. 1). The size of infesting bivalves varied considerably within any one C. maenas, ranging from 2.0 to $11.0 \mathrm{~mm}$ in shell length. At Newton's Cove, a single bivalve was found in one of the 20 C. maenas individuals sampled. This bivalve had a shell length of $6.7 \mathrm{~mm}$ and was wedged between lamellae on the posterior ninth gill. No bivalves were observed in the other five $C$. maenas populations examined (Table 1).

Many of the crabs inspected were missing limbs or bore signs of black spot disease, but mussel infestations did not appear to be particularly associated with disease or with other parasites, such as rhizocephalans. Infested crabs from both Newton's Cove $(\mathrm{CW}=60 \mathrm{~mm})$ and Gullmar Fjord $(\mathrm{CW}=74 \mathrm{~mm}$ and $80 \mathrm{~mm}$ ) were the largest crabs captured at their respective sites. Infested crabs always had red colouration, although most crabs caught were this colour (Table 1). All infested crabs were male, as were all other crabs caught at the sites where infested crabs occurred (Table 1). Gills on which bivalves were attached appeared to be wasted and were entangled by byssal threads.

Sequencing at the Me15/Me16 locus confirmed that infesting bivalves at both Gullmar Fjord and Newton's Cove were M. edulis, rather than other locally occurring, morphologically similar congeners Mytilus galloprovincialis Lamarck, 1819 or M. trossulus. One mussel specimen from each of the two sites was genotyped. A 180-bp fragment was amplified in all cases, consistent with $M$. edulis, but not M. galloprovincialis (126 bp) or M. trossulus (168 bp) (Inoue et al. 1995). Consensus sequences for these four clones, generated through Clustal Omega alignment (www.ebi.ac.uk/Tools/msa/clustalo), were identical for the two mussel specimens, indicating genetic similarity between the mussels infesting Newton's Cove and Gullmar Fjord crabs. A BLAST search (blast.ncbi.nlm.nih.gov/Blast.cgi) of this consensus sequence found a $>99 \%$ identity (179 of 180 bases) to bases 1169 to 1348 of the M. edulis gene for
Fig. 1 Photograph of Mytilus edulis infestations on Carcinus maenas gills from Gullmar Fjord: a view of $M$. edulis (arrows) in C. maenas branchial chamber after removing the carapace, and b detail of $M$. edulis embedded between gill lamellae

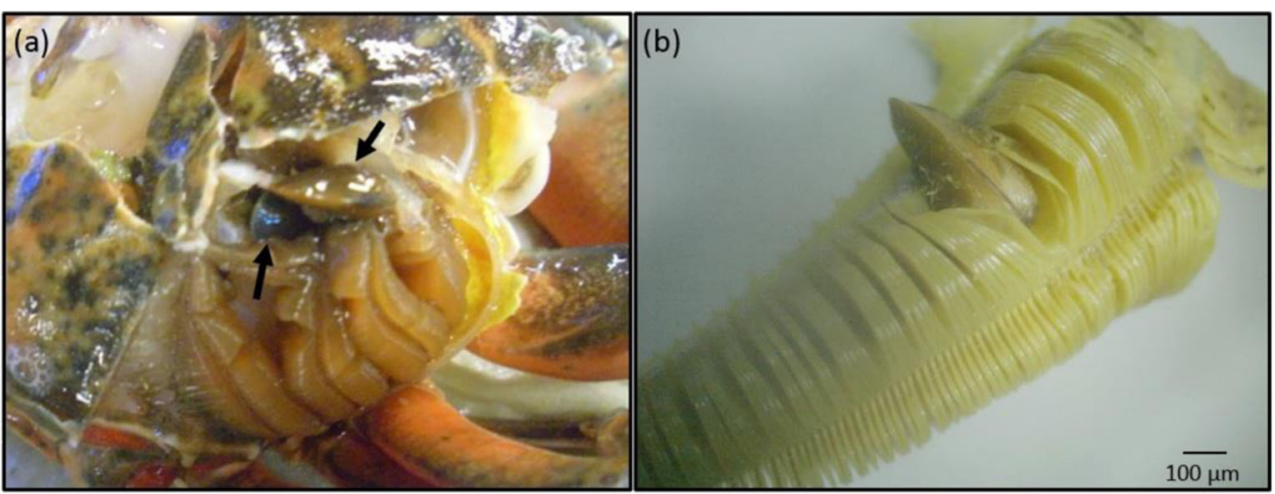


polyphenolic adhesive protein (GenBank accession number X54422.1). Alignment of the sequence against diagnostic sequences for the three Mytilus congeners (Santaclara et al. 2006) indicated clear sequence homology with M. edulis over M. galloprovincialis or M. trossulus (Fig. 2).

\section{Discussion}

We report multiple instances of $M$. edulis inhabiting the branchial chamber of C. maenas. M. edulis were found in three fully mature male $C$. maenas individuals, one from the English Channel and two from Gullmar Fjord. Colonising mussels varied in size, but included some adults. Mussels were found both on the inner carapace and attached directly to the gill, despite the suggestion by MacKenzie et al. (1974) that gill surfaces are an unsuitable site for mussel attachment. Our results, and similar observations of the pedunculate barnacle Octolasmis mülleri (Coker, 1902) on gills of the blue crab Callinectes sapidus Rathbun, 1896 (Walker 1974), suggest that crustacean gills are a viable attachment site for internal commensal species. To our knowledge, this is the first report of such an association between $M$. edulis and C. maenas.

Our observation adds to growing evidence that M. edulis, although typically a free living organism, sometimes colonizes other species. M. edulis larvae have been reported in the gill chambers of haddock Melanogrammus aeglefinus (Linnaeus, 1758) and cod Gadus morhua Linnaeus, 1758 (MacKenzie et al. 1974); however, upon close inspection, the mussels were found to be attached to a parasitic copepod, Lernaeocera sp., and not the gill surface itself (MacKenzie et al. 1974). Bruno (1987) later found post-veliger larvae, thought to be M. edulis, attached to and embedded in the gills of farmed Atlantic salmon Salmo salar Linnaeus, 1758. Post- larval $M$. edulis have been found in the red king crab $P$. camtschaticus, but details of the size of the mussels and the permanence of attachment to the gills were not documented (Jansen et al. 1998). Therefore, our observation establishes that gills of marine animals can be subject to substantial infestation by large mussels and is, to our knowledge, only the second documented example of a bivalve inhabiting crustacean gills.

Assuming that growth rates in branchial chambers are similar to those in the wild, the sizes of the mussels suggest they were from the previous spring spawning period occuring around March to May (Chipperfield 1953). M. edulis exhibits a two-stage settlement, with pediveliger larvae settling preferentially on filamentous substrata in high-flow areas, separate from any adults, before releasing and drifting to a suitable adult habitat (Bayne 1964; Eyster and Pechenik 1987). The veliger larvae most likely entered the branchial chamber accidentally in the inhalant respiratory current of C. maenas and temporarily adhered to the gills (Walker 1974). Only the larvae that immediately attached to the gills would remain in the branchial chamber, as reversal of the respiratory current, aimed to clean debris from the gills, would remove any unattached individuals (Walker 1974). Once the pediveligers metamorphosed $(0.26-0.35 \mathrm{~mm})$ and grew to the post-larval dispersal size $(2.0-2.5 \mathrm{~mm})$ (Bayne 1964), it is unlikely that they would be able to leave the crustacean branchial chamber. Alternatively, $C$. maenas could encounter drifting pediveligers in large numbers whilst feeding on mussel beds (Lane et al. 1985). The accidental inhalation of these post-larval forms could lead to entanglement of the byssus thread around the gills and subsequent new thread production and settlement, similar to the proposed settlement of M. galloprovincialis on the fish parasite Mothocya epimerica Costa, 1851, within the branchial chamber of Atherina boyeri Risso, 1810 (Öktener et al. 2014).

Settled pediveliger larvae in juvenile crabs are likely to be dislodged during ecdysis, before reaching maturity (Shields
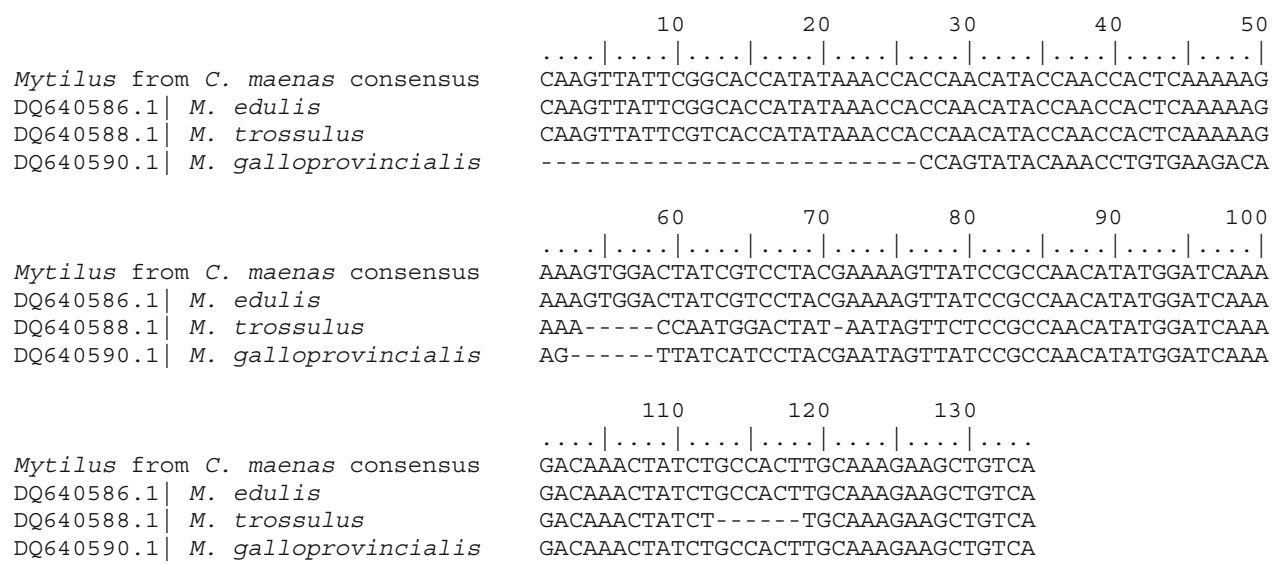

Fig. 2 Clustal Omega sequence alignment (www.ebi.ac.uk/Tools/msa/ clustalo) of a diagnostic region of the polyphenolic adhesive protein gene from bivalves found in Carcinus maenas against reference sequences for Mytilus congeners: M. edulis, M. trossulus and M. galloprovincialis. The consensus sequence represents $100 \%$ identity for four clones from two mussels found in the branchial chamber of C. maenas at Newton's Cove and Gullmar Fjord. Reference sequences were originally published by Santaclara et al. (2006), and are listed with GenBank accession numbers. 
1992), but the prolonged intermoult period of mature crabs would favour the development of infestations (Bauer 1989). New exoskeletons created during moults are always green in appearance, while red crabs will have spent an extended period in intermoult, increasing the chances of mussel colonisation (Styrishave et al. 2004). These red crabs are often the larger males (CW $>60 \mathrm{~mm}$ ) (Reid et al. 1994), which reduce moulting frequency in order to devote energy to reproduction (Styrishave et al. 2004).

Sampling timing may explain why observations of M. edulis infestations in C. maenas are rare. C. maenas populations are commonly sampled during the spring, summer and autumn months while crabs inhabit shallow sublittoral regions (Atkinson and Parsons 1973). Much of this period would be prior to $M$. edulis settlement or when larvae are very small and easily overlooked. From late autumn, mature C. maenas populations migrate offshore (Atkinson and Parsons 1973), so any mature adults infested with M. edulis would not be sampled. Our sampling time of November to December allowed for the collection of mature adults just prior to offshore migration after spring-spawned $M$. edulis had sufficient time to grow.

While consequences of colonisation by $M$. edulis for C. maenas are unknown, it seems unlikely to provide advantages. Presumably, $M$. edulis does not feed directly on the tissue of the host, but the size and number of colonising mussels would create other problems. Attachment of $M$. edulis to the gill and surrounding chamber and waste produced by the mussels could reduce the respiratory efficiency by obstructing the ventilatory stream, impairing gill movements, reducing the exposed gill surface area and removing oxygen in the inhalant water (Walker 1974; Gannon and Wheatly 1992). M. edulis could also obstruct or functionally impair cleaning appendages, further reducing gill efficiency due to fouling (Santos and Bueno 2002) and increasing the likelihood of further infestation. Although moulting might occur when $M$. edulis are small, and could be an important defence against colonisation (Bauer 1989; Walker 1974), large infestations could present a considerable obstruction to moulting. The fact that the only deceased crab at Gullmar Fjord happened to be one of the two infested individuals suggests that consequences could be lethal for the host.

Mussels colonising C. maenas at Gullmar Fjord were highly aggregated in just two individuals. Unless growth rates of colonising mussels were highly variable, these aggregations did not originate from a mass colonisation event, since they consisted of a wide size range of individuals. Reproduction within the host seems unlikely, because this would require long adult residence times and successful retention of offspring. Instead, we suggest that aggregated distributions result from increased chances of subsequent settlement following previous colonisation. Initial colonisation could promote further settlement due to gregarious settlement behaviour (Petersen 1984) or interference with gill cleaning function. In this way, establishment of a single individual could result in further infestation and a rapid deterioration in fitness of the host.

Although $M$. edulis could be acting as a facultative commensal or parasite of $C$. maenas, it seems more likely that this is a case of accidental colonisation, with negative outcomes for the coloniser. Certainly, mussels would be well protected from predators inside $C$. maenas and can likely survive to maturity, which is normally attained during the first year of life (Seed 1969). Since M. edulis is a suspension feeder, food delivery could be enhanced by high flows associated with active irrigation of the gill surfaces by the crab. However, the extensive multi-stage life-cycle of $M$. edulis (Bayne 1964), coupled with the risks of moulting and mortality of $C$. maenas during large infestations, makes it unlikely that reproduction, and therefore fitness, would be improved over a free-living mode of life.

This is the first report of $M$. edulis colonising $C$. maenas branchial chambers and only the second time such an association has been documented between a bivalve and a crustacean. Our finding opens several future lines of enquiry. Because infestations are relatively rare, occurring in only $2.4 \%$ of individuals inspected, more extensive sampling of a greater number of crabs at each site would be necessary to accurately establish the abundance and prevalence of mussels in branchial chambers. Further work is also necessary to fully understand the physiological effects of the relationship, to determine the ability of both $M$. edulis and $C$. maenas to survive in the long term, and therefore to assess ecological consequences. Finally, the environmental conditions or biological scenarios that promote mussel infestations require investigation. The association between $M$. edulis and $C$. maenas could have important ecological implications and provides an intriguing example of a prey species infesting a predatory host.

Acknowledgements The authors thank S. Dupont, B. Lundve, E. Morgan and J. Projecto-Garcia for assistance with crab collection and dissection, and two anonymous reviewers for comments on the manuscript. Work was supported by funding from the UK Natural Environment Research Council (NERC) under grant NE/J007951/1.

Open Access This article is distributed under the terms of the Creative Commons Attribution 4.0 International License (http:// creativecommons.org/licenses/by/4.0/), which permits unrestricted use, distribution, and reproduction in any medium, provided you give appropriate credit to the original author(s) and the source, provide a link to the Creative Commons license, and indicate if changes were made. 


\section{References}

Atkinson RJA, Parsons AJ (1973) Seasonal patterns of migrations and locomotor rhythmicity in populations of Carcinus. Neth J Sea Res 7: 81-93

Bauer RT (1989) Decapod crustacean grooming: Functional morphology, adaptive value, and phylogenetic significance. In: Felgenhauer BE, Watling L, Thistle AB (eds) Functional morphology of feeding and grooming in crustacea. A. A. Balkema, Rotterdam, pp 49-74

Bayne BL (1964) Primary and secondary settlement in Mytilus edulis L. (Mollusca). J Anim Ecol 33:513-523

Bodger PM, Allen JA (2008) The ecology and life cycle of a population of Modiolarca tumida (Hanley, 1843) (Bivalvia: Mytilidae) of the coast off north-eastern England. J Molluscan Stud 74:97-101

Boss KJ (1965) A new mollusk (Bivalvia, Erycinidae) commensal on the stomatopod crustacean Lysiosquilla. Am Mus Novit 2215:1-11

Boyko CB, Williams JD, Markham JC (2012) Recent and fossil Isopoda Bopyridae parasitic on squat lobsters and porcelain crabs (Crustacea: Anomura: Chirostyloidea and Galatheoidea), with notes on nomenclature and biogeography. Zootaxa 1-35

Bristow GA, Berland B, Schander C, Vo DT (2010) A new endosymbiotic bivalve (Heterodonta: Galeommatoidea), from pacific holothurians. J Parasitol 96:532-534

Bruce L (1989) Invertebrates associated with the thinstripe hermit Clibanarius vittatus (Bosc) (Crustacea: Decapoda: Diogenidae) from the Barrier Islands of Mississippi. Gulf Res Rep 8:213-217

Bruno DW (1987) The risk to farmed Atlantic salmon, Salmo sala L., from marine mussels growing on net cages. Bull Eur Assoc Fish Pathol 7:121-123

Chipperfield PNJ (1953) Observations on the breeding and settlement of Mytilus edulis (L.) in British waters. J Mar Biol Assoc UK 32:449476

Eyster LS, Pechenik JA (1987) Attachment of Mytilus edulis L. larvae on algal and byssal filaments is enhanced by water agitation. J Exp Mar Biol Ecol 114:99-110

Gannon AT, Wheatly MG (1992) Physiological effects of an ectocommensal gill barnacle, Octolasmis muelleri, on gas exchange in the blue crab Callinectes sapidus. J Crustac Biol 12:11-18

Goto R, Hamamura Y, Kato M (2007) Obligate commensalism of Curvemysella paula (Bivalvia : Galeommatidae) with hermit crabs. Mar Biol 151:1615-1622

Hatcher MJ, Dick JTA, Dunn AM (2006) How parasites affect interactions between competitors and predators. Ecol Lett 9:1253-1271

Inoue K, Waite JH, Matsuoka M, Odo S, Harayama S (1995) Interspecific variations in adhesive protein sequences of Mytilus edulis, M. galloprovincialis, and M. trossulus. Biol Bull 189:370-375

Isaeva V, Kulikova C, Kasyanov V (2001) Bivalve molluscs, Mytilus trossulus and Hiatella arctica, as facultative epibionts of the crab, Hemigrapsus sanguineus, infested by the rhizocephalan, Sacculina polygenea. J Mar Biol Assoc UK 81:891-892

Jansen PA, MacKenzie K, Hemmingsen W (1998) Some parasites and commensals of red king crabs, Paralithodes camtschaticus (Tilesius), in the Barents Sea. Bull Eur Assoc Fish Pathol 18:46-49

Kato M, Itani G (1995) Commensalism of a bivalve, Peregrinamor ohshimai, with a Thalassinidean burrowing shrimp, Upogebia major. J Mar Biol Assoc UK 75:941-947

Key MM, Jeffries WB, Voris HK, Yang CM (1996) Epizoic bryozoans, horseshoe crabs, and other mobile benthic substrates. Bull Mar Sci 58:368-384

Kosuge T, Itani G (1994) A record of the crab associated bivalve, Pseudopythina macrophthalmensis from Iriomote Island, Okinawa, Japan. Jpn J Malacol 53:241-244

Lane DJW, Beaumont AR, Hunter JR (1985) Byssus drifting and the drifting threads of the young post-larval mussel Mytilus edulis. Mar Biol 84:301-308
Li J, Foighil DÓ, Middelfart P (2012) The evolutionary ecology of biotic association in a megadiverse bivalve superfamily: sponsorship required for permanent residency in sediment. PLoS One 7:e42121

Lützen J, Takahashi T (2003) Arthritica japonica, sp. nov. (Bivalvia: Galeommatoidea: Leptonidae), a commensal with the pinnotherid crab Xenophthalmus pinnotheroides White, 1846. Yuriyagai 9:1119

MacKenzie K, Smith JW, Wootten R (1974) The case of mussel bound fish. Scott Fish Bull 41

McDermott JJ (1991) Incidence and host-parasite relationship of Leidya bimini (Crustacea, Isopoda, Bopyridae) in the Brachyuran Crab Pachygrapsus transversus from Bermuda. Ophelia 33:71-95

Minchella DJ (1985) Host life-history variation in response to parasitism. Parasitology 90:205-216

Mori M, Orecchia S, Biagi F (1999) The occurrence of the bopyrid parasite Pseudione crenulata G.O. Sars (Isopoda, Epicaridea) in the branchial chamber of Munida tenuimana G.O. Sars (Crustacea: Anomura) from North Tyrrhenian Sea. Doriana 7:1-5

Morton B (1972) Some aspects of the functional morphology and biology of Pseudopythina subsinuata (Bivalvia: Leptonacea) commensal on stomatopod crustaceans. J Zool 166:79-96

Mouritsen KN, Poulin R (2005) Parasites boosts biodiversity and changes animal community structure by trait-mediated indirect effects. Oikos 108:344-350

Öktener A, Oliver PG, Çakir DT (2014) Mytilus (Mollusca, Bivalvia) epibiontic on the fish parasite Mothocya epimerica (Crustacea, Isopoda) in the Sea of Marmara, Turkey. J Conchol 41:759-763

Petersen JH (1984) Larval settlement behavior in competing species: Mytilus californianus Conrad and M. edulis L. J Exp Mar Biol Ecol 82:147-159

Poulin R (1999) The functional importance of parasites in animal communities: many roles at many levels? Int J Parasitol 29:903-914

Poulin R, Mouritsen KN (2006) Climate change, parasitism and the structure of intertidal ecosystems. J Helminthol 80:183-191

Reid DG, Abelló P, Warman CG, Naylor E (1994) Size-related mating success in the shore crab Carcinus maenas (Crustacea: Brachyura). J Zool 232:397-407

Rohde K (1984) Zoogeography of marine parasites. Helgol Meeresunters $37: 35-52$

Rosewater J (1984) A new species of leptonacean bivalve from off northwestern Peru (Heterodonta, Veneroida, Lasaeidae). Veliger 27:8189

Santaclara FJ, Espiñeira M, Cabado AG, Aldasoro A, Gonzalez-Lavín N, Vieites JM (2006) Development of a method for the genetic identification of mussel species belonging to Mytilus, Perna, Aulacomya, and other genera. J Agric Food Chem 54:8461-8470

Santos C, Bueno SLS (2002) Infestation by Octolasmis lowei (Cirripedia : Poecilasmatidae) in Callinectes danae and Callinectes ornatus (Decapoda : Portunidae) from São Sebastião, Brazil. J Crustac Biol 22:241-248

Seed R (1969) The ecology of Mytilus edulis L. (Lamellibranchiata) on exposed rocky shores. Oecologia 3:277-316

Shields JD (1992) Parasites and symbionts of the crab Portunus pelagicus from Moreton Bay, eastern Australia. J Crustac Biol 12:94-100

Styrishave B, Rewitz K, Andersen O (2004) Frequency of moulting by shore crabs Carcinus maenas (L.) changes their colour and their success in mating and physiological performance. J Exp Mar Biol Ecol 313:317-336

Wahl M (1989) Marine epibiosis. I. Fouling and antifouling: some basic aspects. Mar Ecol Prog Ser 58:175-189

Walker G (1974) The occurrence, distribution and attachment of the pedunculate barnacle Octolasmis mülleri (Coker) on the gills of crabs, particularly the blue crab, Callinectes sapidus Rathbun. Biol Bull $147: 678-689$ 